\title{
Analisis Pengaruh Stuktur Modal, Ukuran Perusahaan dan Profitabilitas terhadap Price Earning Ratio (PER) Perusahaan Manufaktur yang Terdaftar di BEI Periode 2013-2015
}

\author{
Yosi Stefhani* \\ *Dosen Tetap Program S1 Jurusan Manajemen Fakultas Ekonomi Universitas Satya Negara Indonesia \\ yosi.stefhani@yahoo.com
}

\begin{abstract}
The purpose of this study is to determine whether there is influence of capital structure (Debt To Equity Ratio), firm size (total assets) and profitability (Net Profit Margin) to Price Earning Ratio (PER) at manufacturing companies listed in Indonesia Stock Exchange period 2013-2015. The sample of companies in this study there are 30 manufacturing companies listed on the IDX period 2013-2015. Data analysis technique used is multiple regression. The independent variables in this research are DER, Total Asset and NPM. Dependent variable in this research is PER. The results showed that only NPM affected PER while Total Asset and NPM did not affect PER. The results also show simultaneously all independent variables affect $L Q 45$.
\end{abstract}

Key Words : DER, Total Asset, NPM, PER

\section{PENDAHULUAN}

Investor yang berinvestasi di saham mengharapkan keuntungan yang dalam bentuk deviden atau capital gain. Deviden merupakan laba yang disepakati untuk dibagikan kepada pemegang saham, sementara itu capital gain adalah selisih harga jual saham dengan harga beli saham, dimana harga jual lebih tinggi dibandingkan harga belinya. Jika investor yang mengharapkan capital gain maka harga menjadi faktor yang diperhatikan. Oleh karena itu juga investor sebelum mengambil keputusan berinvestasi di saham akan melakukan analisa sekuritas. Secara teoritis analisa sekuritas dibagi menjadi analisa teknikal dan analisa fundamental. Analisa teknikal adalah teknik untuk memprediksi arah pergerakan harga saham dan indikator pasar saham lainnya berdasarkan pada data pasar historis seperti informasi harga dan volume. Analisa fundamental adalah merupakan analisa sekuritas yang dilakukan secara top down mulai dari analisa ekonomi, analisa industri dan analisa perusahaan. Kemudian dalam analisa fundamental khususnya analisa perusahaan ada dua komponen utama yang diperhatikan yaitu Earning Per Share (EPS) dan Price Earning Ratio (PER). EPS yaitu laba bersih per lembar saham dan PER mengindikasikan besarnya rupiah yang harus dibayarkan investor untuk memperoleh satu rupiah earning perusahaan. Tetapi EPS belum tentu merupakan deviden. EPS menjadi deviden ketika semua laba bersih disepakati dibagikan semua kepada pemegang saham. Banyak investor yang kemudian lebih memperhatikan PER karena dianggap mampu menjadi tolak ukur penilaian saham. Tapi ada fenomena PER yang tidak selalu mengalami peningkatan seperti keinginan investor. Contohnya saja PER perusahaan Darya-Varia Laboratoria Tbk. menunjukan setiap tahun mulai dari tahun 2013 sampai dengan tahun 2016 mengalami penurunan. 
Grafik 1

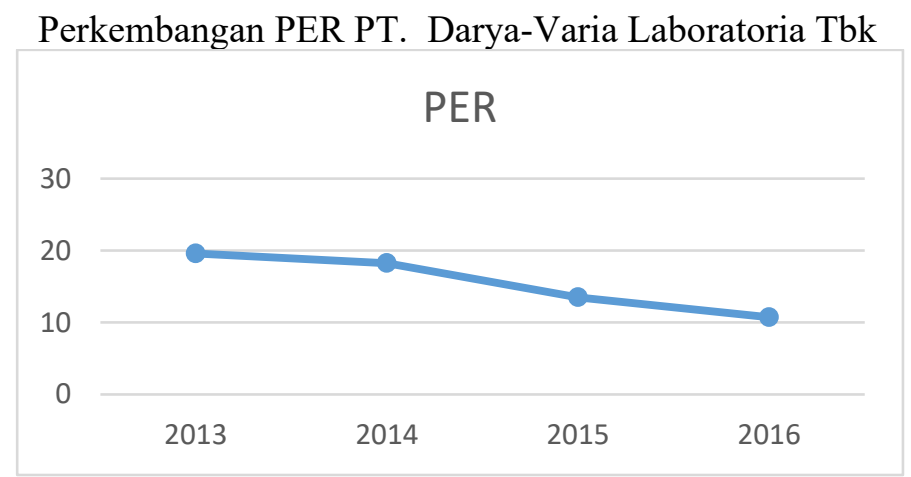

Sumber : Ringakasan Kinerja PT.Darya-Varia Laboratoria Tbk

Penurunan PER diatas mengindikasikan harga saham yang turun. Ini merupakan sinyal yang tidak baik untuk investor. Sehingga faktor-faktor yang mempengaruhi PER juga menjadi sangat penting dan diperhatikan oleh para investor. Secara teoritis beberapa faktor yang mampu mempengaruhi PER adalah struktur modal, ukuran perusahaan, profitabilitas dll.

Salah satu indikator dari struktur modal perusahaan adalah Debt to Equity Ratio. DER yang tinggi menunjukan total hutang yang dimiliki perusahaan tinggi. Hutang yang tinggi berpotensi memunculkan beban bunga tinggi. Bunga yang tinggi berpoensi menyebabkan laba rendah. Laba yang rendah merupakan informasi tidak baik untuk investor sehingga permintaan akan saham tersebut akan rendah dan harga saham rendah. Harga saham yang rendah menyebabkan PER rendah.

Indikator dari ukuran perusahaan adalah total asset yang dimiliki perusahaan. Jika total asset tinggi maka berpotensi menghasilkan pendapatan yang tinggi. Pendapatan yang tinggi berpotensi menghasilkan laba yang tinggi. Informasi ini merupakan informasi yang mampu menyebabkan permintaan akan saham meningkat. Jika permintaan akan saham meningkat maka harga saham meningkat. Jika harga saham meningkat maka PER meningkat.

Profitabilitas yaitu kemampuan perusahaan dalam menghasilkan laba. Salah satu indikator profitabilitas adalah Net Profit Margin (NPM). Jika NPM tingi maka mengindikasikan laba yang diperoleh perusahaan tinggi. Laba yang tinggi menyebabkan permintaan saham naik dan pada akhirnya harga saham naik. Dan ini yang bisa menyebabkan PER naik.

Tapi hubungan teoritis variabel-variabel tadi tidak selalu terbukti. Beberapa penelitian menunjukan perbedaan hasil penelitian. Perbedaan hasil penelitian sebelumnya bisa dilihat di tabel dibawah ini.

Tabel 1

Penelitian Sebelumnya Yang Relevan

\begin{tabular}{|l|l|l|}
\hline \multicolumn{1}{|c|}{ Variabel } & \multicolumn{1}{|c|}{ Peneliti } & \multicolumn{1}{c|}{ Hasil Penelitian } \\
\hline \multirow{5}{*}{ DER } & Mulyani L dan Pitaloka E & DER berperngaruh terhadap PER \\
\cline { 2 - 3 } & Nurul Hayati & DER berpengaruh terhadap PER \\
\cline { 2 - 3 } & Elon Davit Riadi & DER berpengaruh terhadap PER \\
\cline { 2 - 3 } & Vivian Firsera Arisona & DER tidak berpengaruh terhadap PER \\
\cline { 2 - 3 } & Wawan & DER tidak berpengaruh terhadap PER \\
\hline \multirow{3}{*}{ Total Asset } & Elon Davit Riadi & Total assets berpengaruh terhadap price earning ratio \\
\cline { 2 - 3 } & Vivian Firsera Arisona & Total asset tidak berpengaruh terhadap PER \\
\hline NPM & $\begin{array}{l}\text { Ryan El Zamzami, Aulia dan } \\
\text { Fuad Rahman }\end{array}$ & NPM berpengaruh terhadap PE \\
\cline { 2 - 3 } & Danta Sitepu dan Johan Effendi & NPM tidak berpengaruh terhadap PE \\
\hline
\end{tabular}

Sumber : Dari Berbagai Jurnal 
Maka berdasarkan fenomena yang ada dan masih adanya perbedaan hasil penelitian sebelumnya maka penulis tertarik untuk melakukan penelitian dengan topik Analisa Pengaruh Struktur Modal, Total Asset dan Profitabilitas terhadap PER perusahaan manufaktur yang terdaftar di Bursa Efek Indonesia periode 2013-2015.

\section{KERANGKA PEMIKIRAN TEORITIS}

Price earning ratio menjadi salah satu komponen yang diperhatikan ketika melakukan analisa perusahaan yang merupakan rangkaian analisa dalam analisa fundamental sekuritas, secara tidak langsung PER menjadi variabel yang menentukan apakah pada akhirnya investor akan membeli saham tersebut atau tidak. Sementara itu fenomena yang terjadi menunjukkan PER tidak selalu meningkat, padahal bagi investor yang memiliki saham tertentu mengharapkan PER mengalami kenaikan yang menunjukan kenaikan harga saham. Oleh karena itu pentingnya PER menyebabkan faktor-faktor yang mempengaruhi juga menjadi penting untuk diperhatikan. Beberapa faktor yang secara teoritis mampu mempengaruhi PER diantaranya :

1. Struktur Modal

Struktur modal merupakan komposisi modal yang dimiliki perusahaan yang terdiri dari hutang dan ekuitas. Salah satu indikator struktur modal adalah Debt to Equity Ratio (DER). Variabel ini diasumsikan mampu mempengaruhi PER. Nilai DER yang tinggi maka berpotensi mengindikasikan beban bunga akan tinggi, beban bunga tinggi berpotensi mengurangi laba bersih cukup besar. Laba bersih yang rendah akan menjadi informasi yang tidak baik bagi para investor sehingga membuat permintaan akan saham tersebut menurun dan pada akhirnya mampu menyebabkan harga saham menjadi turun. Harga saham yang turun membuat PER menjadi rendah.

2. Ukuran Perusahaan

Ukuran perusahaan mengindikasikan besar atau kecil suatu perusahaan. Indikator yang sering digunakan untuk ukuran perusahaan adalah total asset yang dimiliki perusahaan. Variabel ini diasumsikan mampu mempengaruhi PER. Total asset yang tinggi berpotensi menghasilkan pendapatan yang tinggi, pendapatan yang tinggi berpotensi menghasilkan laba yang tinggi. Informasi laba yang tinggi merupakan informasi yang baik bagi investor sehingga mampu menyebabkan permintaan akan saham meningkat dan pada akhirnya meningkatkan harga saham. Kenaikan harga saham yang membuat PER naik.

3. Profitabilitas

Profitabilitas merupakan kemampuan perusahaan untuk menghasilkan laba. Salah satu indikator profitabilitas adalah Net Profit Margin (NPM). Nilai NPM yang tinggi mengindikasikan laba yang tinggi. Laba yang tinggi seperti berpotensi meningkatakan permintaan akan saham dan membuat harga naik. Kenaikan harga membuat PER ikut naik.

4. Likuidtas

Likuiditas adalah kemampuan perusahaan untuk membayar kewajiban hutang jangka pendeknya. Salah satu indikator likuiditas adalah current ratio. Curent ratio yang tinggi mengindikasikan kemampuan yang baik perusahaan dalam membayar kewajiban jangka pendeknya. Jika perusahaan memiliki kemampuan membayar jangka pendek dengan baik maka mengindikasikan kegiatan operasional perusahaan lancar. Dengan kondisi seperti ini mengindikasikan kesehatan keuangan perusahaan baik. Kondisi ini mengindikasikan informasi kondisi perusahaan baik. Informasi ini merupakan informasi yang baik bagi investor dan mampu menaikan harga saham dan pada akhirnya menaikkan PER

Penelitian terkait PER telah banyak dilakukan walaupun dengan hasil penelitian yang berbeda-beda. Penelitian-penelitian sebelumnya yang relevan akan dijelaskan berikut ini. 
Penelitian yang dilakukan oleh Mulyani dan Pitaloka pada tahun 2017. Variabel indenpenden yang diteliti adalah Return on Equity (ROE), Earning Per Share (EPS) dan DER. Penelitian ini merupakan penelitian studi kasus PT. Indofood Sukser Makmur Tbk periode 20122014. Analisis data yang digunakan adalah regresi berganda. Variabel independen yang berpengaruh terhadap PER adalah ROE dan DER. Sementara itu EPS tidak berpengaruh terhadap PER.

Penelitian yang dilakukan oleh Wawan Utomo dkk pada tahun 2016. Variabel indenpenden yang diteliti adalah DER, Price Book Value (PBV), Ukuran Perusahaan, Return on Equity (ROE), Deviden Payout Ratio (DPR) dan Likuiditas. Sampel yang digunakan adalah 12 perusahaan yang listing di BEI periode tahun 2009 - 2014. Analisis data yang digunakan adalah regresi berganda. Dari 6 variabel independen yang diteliti variable yang berpengaruh terhadap PER adalah PBV dan ROE, sementara 4 variabel lainnya DER, DPR,CR dan ukuran perusahaan tidak berpengaruh terhadap PER.

Penelitian yang dilakukan oleh Danta Sitepu dan Johan Effendi tahun 2014. Variabel indenpenden yang diteliti adalah harga saham, laba bersih, jumlah saham beredar dan deviden. Sampel yang digunakan adalah 13 perusahaan sektor customer goods yang listing di BEI periode tahun 2007-2011. Analisis data yang digunakan adalah regresi berganda. Variabel independen yang berpengaruh terhadap PER adalah jumah saham beredar dan deviden. Sementara itu laba bersih dan harga saham tidak berpengaruh terhadap PER.

Penelitian yang dilakukan oleh Elon Davit Riadi pada tahun 2013. Variabel indenpenden yang diteliti adalah DER, Total Assset dan Return on Equity (ROE). Sampel yang digunakan adalah 12 perusahaan yang listing di BEI periode tahun 2005 - 2010. Analisis data yang digunakan adalah regresi berganda. Semua variabel independen yang diteliti ternyata berpengaruh PER.

Penelitian yang dilakukan oleh Vivian Firsera Arisona tahun 2013. Variabel indenpenden yang diteliti adalah DPR, Pertumbuhan Laba, ROE, DER dan Ukuran perusahaan. Sampel yang digunakan adalah perusahaan termasuk indeks LQ45 yang listing di BEI periode tahun 2008-2010. Analisis data yang digunakan adalah regresi berganda. Variabel independen yang berpengaruh terhadap PER adalah DPR dan ROE. Sementara itu pertumbuhan laba, DER, ukuran perusahaan tidak berpengaruh terhadap PER.

Penelitian yang dilakukan oleh Nurul pada tahun 2010. Variabel indenpenden yang diteliti adalah EPS, Return on Asset (ROA), DER, ROE dan Price Book Value. Sampel yang digunakan adalah perusahaan sektor real estate dan properti yang listing di BEI periode tahun 2006. Analisis data yang digunakan adalah regresi berganda. Variabel independen yang berpengaruh terhadap PER adalah EPS, ROA, DER dan ROE. Sementara itu PBV tidak berpengaruh terhadap PER.

Berdasarkan penjelasan diatas maka dapat dikembangkan kerangka pemikiran teoritis seperti dibawah ini:

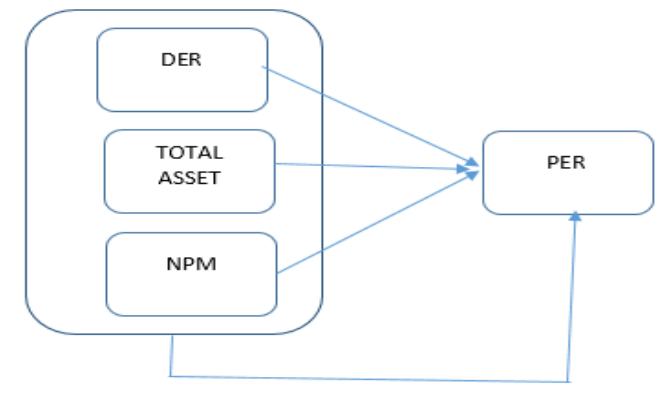

Gambar 1

Kerangka Pemikiran 


\section{Hipotesis}

Hipotesis yang diajukan dalam penelitian ini adalah :

Hipotesis 1:

Ho $\quad$ : DER tidak berpengaruh terhadap PER

Ha : DER berpengaruh terhadap PER

Hipotesis 2:

Ho $\quad:$ Total Asset tidak berpengaruh terhadap PER

Ha $\quad$ : Total Asset berpengaruh terhadap PER

Hipotesis 3:

Ho $\quad:$ NPM tidak berpengaruh terhadap PER

Ha : NPM berpengaruh terhadap PER

Hipotesis 4:

Ho $\quad$ : DER, Total Asset, NPM tidak berpengaruh terhadap PER

Ha $\quad$ : DER, Total Asset, NPM berpengaruh terhadap PER

\section{METODE}

\section{Populasi dan Sampel}

Populasi dalam penelitian ini adalah seluruh perusahaan manufaktur yang terdaftar di Bursa Efek Indonesia periode tahun 2013-2015. Teknik pengambilan sampling yang digunakan adalah purposive sampling yaitu teknik penentuan sampel yang didasarkan dengan beberapa kriteria tertentu. Kriteria yang digunakan dalam penelitian ini adalah Perusahaan manufaktur yang memiliki data keuangan yang lengkap yang diperlukan dalam penelitian ini.

\section{Desain Penelitian}

Dalam penelitian ini desain penelitian yang digunakan yaitu Penelitian Kausal, yaitu penelitian yang bertujuan untuk mengetahui pengaruh antara satu atau lebih variabel independen terhadap variabel dependen.

\section{Jenis dan Sumber Data}

Jenis data yang digunakan dalam penelitian ini adalah data sekunder. Data yang berupa rasio rasio- keuangan perusahaan perusahaan periode 2013-2015. Sumber data diperoleh dari ringkasan kinerja yang diterbitkan.

\section{Definisi Operasional Variabel}

Variabel penelitian dan definisi operasional berdasarkan pada masalah dan hipotesis yang akan di uji, yaitu sebagai berikut : 
Tabel 2

Operasionalisasi Variabel

\begin{tabular}{|l|l|c|}
\hline \multicolumn{1}{|c|}{ Variabel } & \multicolumn{1}{|c|}{ Indikator } & Pengukuran \\
\hline $\begin{array}{l}\text { struktur modal yang } \\
\text { merupakan proporsi modal } \\
\text { perusahaan yang erasal dari } \\
\text { hutang dan modal sendiri. }\end{array}$ & Debt To Equty Ratio (DER) & DER $=\frac{\text { Total Debt }}{\text { Total Equity }}$ \\
\hline $\begin{array}{l}\text { Ukuran Perusahaan adalah } \\
\text { skala perusahaan yang } \\
\text { dilihat dari total aktiva } \\
\text { perusahaan pada akhir tahun }\end{array}$ & Total Asset & Total Asset \\
\hline $\begin{array}{l}\text { Profitabillitas adalah } \\
\text { kemampuan perusahaan } \\
\text { menghasilkan laba Nat Profit Margin (NPM) }\end{array}$ & NPM $=\frac{\text { Laba Bersih }}{\text { Total Pendaptan }}$ \\
\hline Price Earning Rasio (PER) & $\begin{array}{l}\text { Mengindikasikan besarnya } \\
\text { rupiah yang harus dibayarkan } \\
\text { investor untuk memperoleh } \\
\text { satu rupiah earning perusahaan }\end{array}$ & PER $=\frac{\text { Harga saham }}{\text { Earning per lembar saham }}$ \\
\hline
\end{tabular}

\section{Teknik Analisis Data}

1. Analisis deskriptif

Metode analisis deskriptif merupakan metode yang digunakan untuk menganalisis data-data yang tersedia dan diolah sehingga diperoleh gambaran yang jelas mengenai fakta-fakta fenomena yang diteliti.

2. Uji Normalitas Data

Karena pengujian hipotesis dalam penelitian ini menggunakan uji regresi berganda yang merupakan statistik parametrik maka terlebih dahulu dilakukan pengujian normalitas data. Pengujian normalitas data menggunakan uji Kolmogorof Smirnov yaitu dengan melihat angka nilai signifikansinya lebih dari 0.05 .

3. Analisa regresi berganda

Model regresi linier dikatakan sebagai model yang baik hanya jika model tersebut memenuhi asumsi-asumsi klasik yaitu data residual terdistribusi normal, tidak adanya multikolinieritas, autokorelasi dan heterokedastisitas.

\section{Uji Asumsi Klasik}

- Uji Normalisasi Residual

Uji ini bertujuan untuk menguji apakah residual telah terdistribusi normal. Model regresi yang baik adalah yang memiliki residual terdistribusi normal. Menguji normalitas residual, dapat dilihat pada grafik probability plot. Data residual dapat dikatakan normal bila data residual atau titik titik tersebar disekitar garis diagonal dan penyebarannya mengikuti garis diagonalnya.

\section{- Uji Multikolinieritas}

Uji multikolinieritas bertujuan untuk menguji apakah model regresi ditemukan adanya korelasi antar variabel bebas. Model regresi yang baik seharusnya tidak terjadi korelasi diantara variabel bebas. Untuk mendeteksi ada atau tidaknya gejala multikolinieritas dalam suatu model regresi dapat diketahui dari Variance Inflation Factor (VIF) apabila nilai VIF kurang dari 10 dan Tolerance lebih dari 0,1 maka dinyatakan tidak terjadi multikolinieritas. 


\section{- Uji Autokorelasi}

Uji ini bertujuan untuk menguji apakah dalam model regresi linier ada korelasi antara kesalahan pengganggu pada periode $\mathrm{t}$ dengan kesalahan pengganggu pada periode $\mathrm{t}-1$ (sebelumnya). Pengujian ada tidaknya autokorelasi dalam persamaan ini digunakan uji Durbin Watson (DW - test). Model regresi yang baik adalah model yang tidak mengandung autokorelasi. Jika nilai uji statistic Durbin-Watson lebih kecil dari satu atau lebih besar dari tiga, maka model regresi mengandung autokorelasi.

- Uji Heteroskedastisitas

Uji heteroskedastisitas bertujuan untuk menguji apakah dalam sebuah model regresi terjadi ketidaksamaan varians dari suatu pengamatan ke pengamatan yang lain. Model regrasi yang baik adalah seharusnya tidak terjadi heteroskedastisitas. Uji heteroskedastisitas bisa dengan melihat pola titik-titik pada grafik regresi. Jika tidak ada pola yang jelas, seperti titik-titik menyebar di atas dan dibawah angka 0 pada sumbu Y, maka tidak terjadi heteroskedastisitas.

\section{Analisis Regresi Linear Berganda}

Metode analisis regresi linear berganda merupakan suatu bentuk hubungan linear antara dua atau lebih variabel independen dengan variabel dependennya.

\section{Uji t}

Digunakan untuk membuktikan pengaruh variabel independen terhadap variabel dependen secara individu atau parsial. Dalam pengujian ini sebelumnya dirumuskan hipotesisnya.

Ho : : Variabel Independen tidak berpengaruh terhadap variabel dependen

$\mathrm{Ha} \quad$ : Variabel Independen berpengaruh terhadap variabel dependen

Kriteria pengujian untuk uji t sebagai berikut :

Jika $\mathrm{t}$ tabel $\leq \mathrm{t}$ hitung $\leq \mathrm{t}$ tabel maka Ho diterima

Jika $\mathrm{t}$ tabel $<\mathrm{t}$ hitung $\leq$ atau $\mathrm{t}$ hitung $>\mathrm{t}$ tabel maka Ho ditolak

Berdasarkan signifikansi:

Jika Signifikansi > 0,05 maka Ho diterima

\section{Uji F}

Uji ini merupakan pengujian untuk pengaruh dari variabel-variabel independen secara simultan terhadap variabel dependen. Dalam pengujian ini sebelumnya dirumuskan hipotesisnya.

Ho : Variabel-Variabel Independen secara simultan tidak berpengaruh terhadap variabel dependen

Ha : Variabel- variabel Independen secara simultan berpengaruh terhadap variabel dependen

Kriteria pengujian untuk uji F sebagai berikut :

Jika $\mathrm{F}$ tabel $\leq \mathrm{F}$ hitung maka Ho diterima

Jika $\mathrm{F}$ tabel $>$ F Hitung maka Ho ditolak

Berdasarkan signifikansi:

Jika Signifikansi $>0,05$ maka Ho diterima

Jika Signifikansi $<0,05$ maka Ho ditolak 
Model Regresi Berganda dalam penelitian ini adalah sebagai berikut:

$$
\begin{aligned}
& \mathrm{Y}=\mathrm{a}+\mathrm{b} 1 \mathrm{x} 1+\mathrm{b} 2 \times 2+\mathrm{b} 3 \times 3++\mathrm{e} \\
& \text { Keterangan: } \\
& \mathrm{Y}=\text { PER } \\
& \mathrm{a}=\text { Konstanta } \\
& \mathrm{b} 1-\mathrm{b} 5=\text { Koefisien regresi variabel independen } \\
& \mathrm{x} 1=\text { DER } \\
& \mathrm{x} 2=\text { Total Assets } \\
& \mathrm{x} 3=\text { NPM } \\
& \mathrm{e}=\text { error te }
\end{aligned}
$$

\section{PEMBAHASAN}

Pengolahan data dalam penelitian ini menggunakan analisis regresi berganda sehingga seluruh data harus melewati uji normalitas data terlebih dahulu. Dengan demikian dalam penelitian ini menggunakan 84 observasi, tetapi dari seluruh observasi ini terdapat 24 observasi yang dikeluarkan dari pengamatan (outlier) karena tiap variabel memiliki nilai yang terlalu tinggi atau terlalu rendah (ekstrim) sehingga total observasi dalam penelitian ini berjumlah 60 observasi.

\section{Analisa Deskriptif}

Analisa deskriptif bertujuan untuk memberikan gambaran tentang data yang digunakan dalam penelitian ini. Data terlebih dahulu ditinjau mengenai deskripsi variabel penilaian dengan analisis statistik deskriptif. Statistik deskriptif dapat dilihat dari nilai rata-rata (mean),maksimal dan minimum. Selengkapnya mengenai hasil statistik deskriptif penilaian dapat dilihat pada tabel 4.2 sebagai berikut :

Tabel 3

\begin{tabular}{|l|r|r|r|r|r|}
\hline \multicolumn{7}{|c|}{ Descriptive Statistics } & \multicolumn{1}{|c|}{ Mean } & \multicolumn{1}{c|}{ Std. Deviation } \\
\hline DER & N & Minimum & \multicolumn{1}{c|}{ Maximum } & \multicolumn{1}{c|}{ Mean } \\
TA * & 60 & .08 & 3.03 & .8643 & .55853 \\
NPM & 60 & 159952.00 & 91831526.00 & 8108570.5667 & 18704206.99413 \\
PER & 60 & -4.05 & 26.60 & 7.7345 & 5.40616 \\
Valid N (listwise) & 60 & -10.77 & 45.65 & 21.3622 & 11.62655 \\
\hline
\end{tabular}

Catatan;

*Nilai total asset dalam jutaan rupiah

Dari tabel diatas maka nilai rata-rata setiap variabel dalam penelitian ini untuk DER mempunyai nilai rata-rata 0,8643 , Total Asset nilai rata-ratanya Rp 8.108.570.566.700, NPM nilai rata-rata 7,7345 dan PER nilai rata-ratanya 21,3622.

\section{Uji Normalitas Data}

Pengujian dalam penelitian ini menggunakan analisa regresi berganda. Regresi berganda merupakan salah satu analisa parametrik. Syarat wajib untuk bisa menggunakan analisa parametrik adalah data yang diuji merupakan data yang terdistribusi normal. Maka langkah pertama dalam pengujian penelitian ini melakukan pengujian normalitas data. Uji normalitas data yang digunakan dalam penelitian ini adalah Kolmogorov smirnov. Berikut ini merupakan hasil uji normalitas data menggunakan Kolmogorov Smirnov. 
Tabel 4

Hasil Uji Normalitas Data

Tests of Normality

\begin{tabular}{|l|r|r|r|r|r|r|}
\hline & \multicolumn{3}{|c|}{ Kolmogorov-Smirnov $^{\mathrm{a}}$} & \multicolumn{3}{c|}{ Shapiro-Wilk } \\
\cline { 2 - 7 } & Statistic & \multicolumn{1}{c|}{ df } & \multicolumn{1}{c|}{ Sig. } & Statistic & \multicolumn{1}{c|}{ df } & \multicolumn{1}{c|}{ Sig. } \\
\hline DER & .108 & 60 & .079 & .893 & 60 & .000 \\
TOTAL ASSET & .092 & 60 & $.200^{*}$ & .967 & 60 & .098 \\
NPM & .112 & 60 & .057 & .956 & melebihi60 & .031 \\
PER & .111 & 60 & .062 & .941 & 60 & .006 \\
\hline
\end{tabular}

*. This is a lower bound of the true significance.

a. Lilliefors Significance Correction

Berdasarkan hasil uji normalitas data menunjukan bahwa tingkat signikansi untuk setiap variabel lebih dari 0,05 maka dapat diambil kesimpulan bahwa data sampel penelitian ini terdistribusi normal. Langkah selanjutnya dalam pengujian berikutnya adalah uji asumsi klasik

\section{Uji Asumsi Klasik}

Uji asumsi klasik diperlukan untuk memastikan model regresi berganda merupakan model regresi yang baik. Berikut ini merupakan hasil uji asumsi klasik yang terdiri dari uji normalitas residual, uji multikolinieritas, autokolerasi dan heterokedastisitas.

\section{Uji Normalitas Residual}

Model regresi yang baik adalah model regresi yang memiliki nilai residual yang terdistribusi normal.

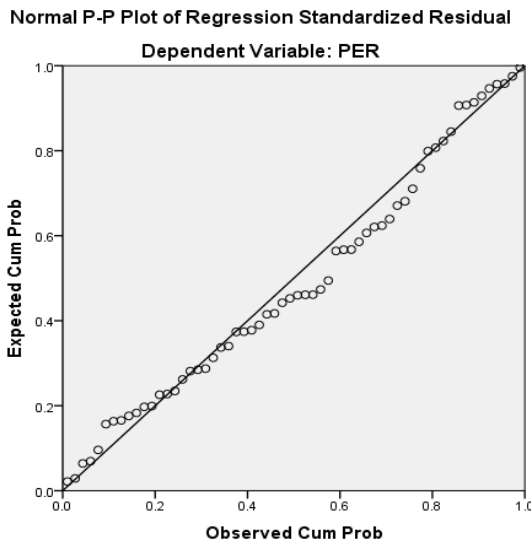

Gambar 2

\section{Hasil Uji Normalitas Residual}

Berdasarkan uji normalitas residual terlihat data mendekati garis P-Plot menunjukan bahwa nilai residual terdistribusi normal.

\section{Uji Multikolinieritas}

Pengujian multikolinieritas dalam penelitian ini dengan cara meregresikan model analisis dan melakukan uji korelasi antar variabel independen dengan menggunakan Tolerance dan Varians Inflating Factor (VIP). Berikut ini merupakan hasil uji multikolinieritas : 
Tabel 5

Hasil Uji Multikolinieritas

\begin{tabular}{|ll|r|r|}
\hline \multirow{2}{*}{\multicolumn{2}{|c|}{ Model }} & \multicolumn{2}{|c|}{ Collinearity Statistics } \\
\cline { 2 - 3 } & Tolerance & \multicolumn{1}{c|}{ VIF } \\
\hline 1 & (Constant) & & \\
& DER & .936 & 1.068 \\
& TOTAL ASSET & .888 & 1.126 \\
& NPM & .835 & 1.198 \\
\hline
\end{tabular}

Dari hasil pengujian terlihat bahwa nilai Tolerance lebih dari 0,1 dan VIF kurang dari 10 maka dinyatakan tidak terjadi multikolinieritas.

\section{Uji Autokorelasi}

Pengujian autokorelasi dalam penelitian ini menggunakan uji Durbin-Watson. Berikut ini merupakan hasil uji Autokorelasi.

Tabel 6

Hasil Uji Autokorelasi

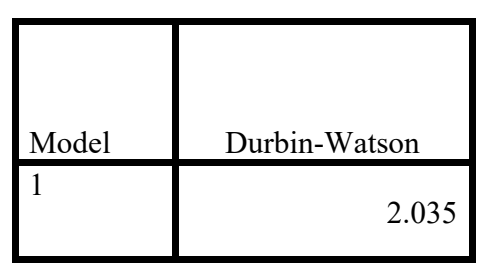

Nilai DW menunjukan lebih besar dari 3 dan kurang dari 3 makaartinya model regresi dalam penelitian tidak terjadi autokorelasi

\section{Uji Heterokedastisitas}

Pengujian heteroskedastisitas dalam penelitian ini dengan melihat Scatterplot. Berikut ini merupakan hasil uji Autokorelasi:

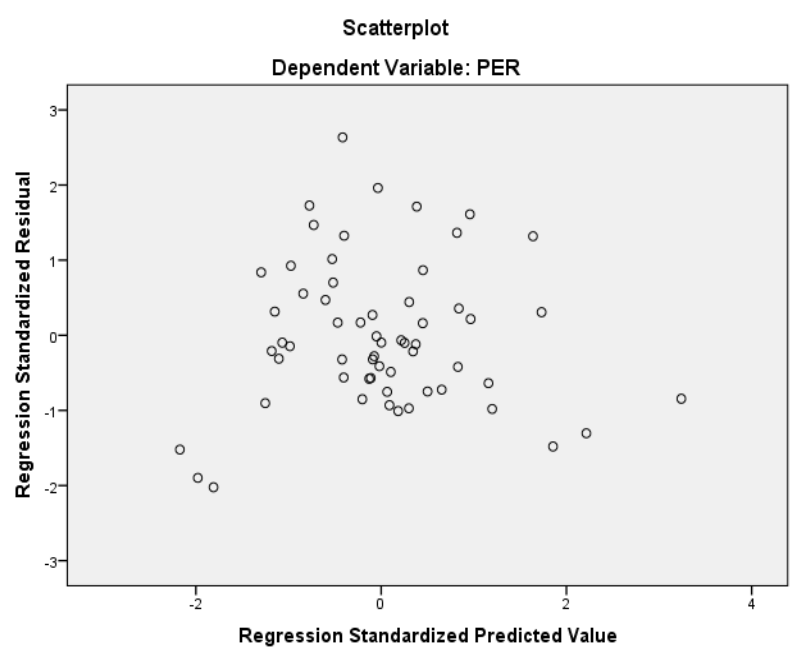

Gambar 3 
Hasil pengujian uji heteroskedastisitas diatas terlihat tidak ada pola yang jelas, dimana titik-titik menyebar di atas dan dibawah angka 0 pada sumbu Y, maka ini menunjukan tidak terjadi heteroskedastisitas.

Setelah melakukan pengujian asumsi klasik, langkah berikutnya melakukan pengujian hipotesis dengan menggunakan uji regresi berganda.

\section{Uji Regresi Berganda}

\section{Hasil Uji F}

Uji F (Uji Simultan) adalah untuk melihat pengaruh variabel bebas terhadap variabel terikatnya secara simultan. Untuk melihat hasil pengujian dapat dilihat pada tabel Anova. Berikut adalah nilai $\mathrm{F}$ hitung dan signifikansi dalam tabel berikut ini.

Tabel 7

Hasil Uji F

\begin{tabular}{|l|r|r|r|r|r|}
\hline Model & Sum of Squares & df & Mean Square & F & \multicolumn{1}{c|}{ Sig. } \\
\hline 1 Regression & 3265.337 & 3 & 1088.446 & 12.941 & $.000^{\mathrm{b}}$ \\
Residual & 4710.089 & 56 & 84.109 & & \\
Total & 7975.427 & 59 & & & \\
\hline
\end{tabular}

a. Dependent Variable: PER

b. Predictors: (Constant), NPM, DER, TOTAL ASSET

Hasil pengujian uji $\mathrm{F}$ menunjukan nilai signifikan yang diperoleh adalah 0,000 berarti lebih kecil dari tingkat signifikansi 0,05. Karena nilai sig lebih kecil dari 0,05 maka Ho ditolak. Sehingga dapat disimpulkan bahwa DER, Total Asset dan NPM secara simultan berpengaruh terhadap PER.

\section{Hasil Uji t}

Uji t (Uji Parsial) digunakan untuk melihat pengaruh variabel-variabel bebas secara parsial terhadap variabel terikatnya.untuk melihat hasil pengujian dapat melihat tabel Coefficients. Berikut ini adalah hasil pengitungan nilai t hitung dan taraf signifikannya dalam tabel berikut ini.

Tabel 8

Hasil Uji t

\begin{tabular}{|c|c|c|c|c|c|c|}
\hline \multirow{2}{*}{\multicolumn{2}{|c|}{ Model }} & \multicolumn{2}{|c|}{ Unstandardized Coefficients } & \multirow{2}{*}{$\begin{array}{c}\begin{array}{c}\text { Standardized } \\
\text { Coefficients }\end{array} \\
\text { Beta }\end{array}$} & \multirow[b]{2}{*}{$\mathrm{t}$} & \multirow[b]{2}{*}{ Sig. } \\
\hline & & $\mathrm{B}$ & Std. Error & & & \\
\hline \multirow[t]{4}{*}{1} & (Constant) & 3.998 & 12.078 & & .331 & .742 \\
\hline & DER & -.487 & 2.247 & -.023 & -.217 & .829 \\
\hline & TOTAL ASSET & .510 & .845 & .066 & .604 & .548 \\
\hline & NPM & 1.334 & .242 & .620 & 5.519 & .000 \\
\hline
\end{tabular}

Hasil pengujian uji t menunjukan nilai signifikan untuk setiap variabel independen. Dari 3 variabel independen hanya satu variabel independen yaitu NPM yang nilai signifikansi lebih kecil dari 0,05 maka Ho ditolak. Sementara itu 2 variabel independen lainnya yaitu DER dan Tortal Asset memperoleh nilai signifikansinya lebih besar dari 0,05 maka Ho diterima. Dengan 
hasil pengujian ini maka dapat simpulkan bahwa hanya variabel NPM yang berpengaruh terhadap PER, sementara DER dan Total Asset tidak berpengaruh terhadap PER.

\section{Uji Koefisien Determinasi $\left(\mathbf{R}^{2}\right)$}

Untuk mengetahui besar pengaruh variabel bebas secara simultan berpengaruh terhadap variabel terikat dengan melihat nilai $R$-Square pada tabel berikut ini.

Tabel 9

Hasil Uji Koefisien Determinasi

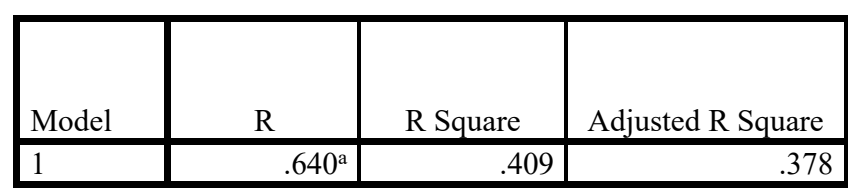

Dari hasil pengolahan data menunjukan Adjusted R Square menunjukan bahwa 0,378 berarti sekitar 37,8\% dari variabel perubahan PER dapat dijelaskan oleh variabel independennya.

\section{Persamaan Regresi}

Berdasarkan hasil pada tabel Coefficients tersebut, dapat disusun persamaan regresi linier berganda sebagai berikut:

Tabel 10

\begin{tabular}{|c|c|c|c|c|c|c|}
\hline \multirow{2}{*}{\multicolumn{2}{|c|}{ Model }} & \multicolumn{2}{|c|}{ Unstandardized Coefficients } & $\begin{array}{c}\text { Standardized } \\
\text { Coefficients }\end{array}$ & \multirow[b]{2}{*}{$\mathrm{t}$} & \multirow[b]{2}{*}{ Sig. } \\
\hline & & $\mathrm{B}$ & Std. Error & Beta & & \\
\hline \multirow[t]{4}{*}{1} & (Constant) & 3.998 & 12.078 & & .331 & .742 \\
\hline & DER & -.487 & 2.247 & -.023 & -.217 & .829 \\
\hline & TOTAL ASSET & .510 & .845 & .066 & .604 & .548 \\
\hline & NPM & 1.334 & .242 & .620 & 5.519 & .000 \\
\hline
\end{tabular}

$$
\mathrm{Y}=3,998-0,487 \mathrm{X}_{1}+0,510 \mathrm{X}_{2}+1,334 \mathrm{X}_{3}
$$

\section{Perbandingan Hasil Penelitian dengan Teori}

1. Secara teoritis DER mampu mempengaruhi PER. Nilai DER yang tinggi maka berpotensi mengindikasikan beban bunga akan tinggi, beban bunga akan tinggi berpotensi mengurangi laba bersih cukup besar. Laba bersih yang rendah akan menjadi informasi yang tidak baik bagi para investor sehingga membuat permintaan akan saham tersebut menurun dan pada akhirnya mampu menyebabkan harga saham menjadi turun. Harga saham yang turun membuat PER menjadi rendah. Tetapi hasil penelitian menunjukan bahwa DER tidak berpengaruh terhadap PER berarti tidak sesuai dengan teori. Asumsi argumentasi untuk hal ini bisa dikarenakan rata-rata nilai DER yang menjadi sampel penelitian ini relatif kecil yaitu 0,08643 jika dibandingkan dengan rata-rata nilai DER populasi yaitu sebesar 1,453.

2. Secara teoritis total asset mampu mempengaruhi PER. Total asset yang tinggi berpotensi menghasilkan pendapatan yang tinggi, pendapatan yang tinggi berpotensi menghasilkan laba yang tinggi. Informasi laba yang tinggi merupakan informasi yang baik bagi investor sehingga mampu menyebabkan permintaan akan saham meningkat dan pada akhirnya meningkatkan harga saham. Kenaikan harga saham yang membuat PER naik. Hasil penelitian menunjukkan Total Asset tidak berpengaruh terhadap PER berarti tidak sesuai dengan teori. Asumsi argumentasi untuk hal ini bisa dikarenakan total asset yang besar belum tentu mampu menghasilkan laba yang tinggi juga karena pengelolaan assetyang 
maksimal dan efisien serta efisiensi biaya-biaya operasional juga mampu mempengaruhi laba. Bisa jadi jika total asset tinggi jika manajemen pengelolaan asset tidak maksimal tidak akan mampu menghasilkan pendapatan yang maksimal. Demikian juga jika biaya-biaya operasional juga tidak efisien tetap akan menghasilkan laba yang kecil.

3. Secara teoritis NPM mampu mempengaruhi PER. Nilai NPM yang tinggi mengindikasikan laba yang tinggi. Laba yang tinggi seperti penjelasan diatas akan membuat harga naik karena menarik investor untuk membeli saham tersebut. Kenaikan harga membuat PER ikut naik. Hasil penelitian menunjukkan NPM berpengaruh terhadap PER maka hal ini sesuai dengan teori.

4. Hasil penelitian yang terakhir menunjukan DER, Total Asset dan NPM secara simultan bepengaruh terhadap PER. Hasil penelitian ini menunjukan kesesuaian dengan teori.

\section{Perbandingan Hasil Penelitian dengan Penelitian Sebelumnya}

Hasil penelitian ini kemudian dibandingkan dengan penelitian sebelumnya yang relevan yang telah disebutkan di bab 2. Berikut hasil perbandingan hasil penelitian dengan penelitian sebelumnya.

\section{Tabel 11}

Perbandingan Hasil Penelitian dengan Penelitian Sebelumnya

\begin{tabular}{|c|c|c|c|}
\hline No. & Hasil Penelitian & \multicolumn{2}{|c|}{ Penelitian Sebelumnya } \\
\hline & & Konsisten & Tidak Konsisten \\
\hline 1. & $\begin{array}{l}\text { DER Tidak Berpengaruh Terhadap } \\
\text { PER }\end{array}$ & $\begin{array}{l}\text { 1. Vivian Firsera } \\
\text { Arisona } \\
\text { 2. Wawan }\end{array}$ & $\begin{array}{ll}\text { 1. } & \text { Mulyani L dan } \\
& \text { Pitaloka E } \\
\text { 2. } & \text { Nurul Hayati } \\
\text { 3. } & \text { Elon Davit Riadi }\end{array}$ \\
\hline 2. & $\begin{array}{l}\text { Total Asset Tidak Berpengaruh } \\
\text { Terhadap PER }\end{array}$ & $\begin{array}{l}\text { 1. Vivian Firsera } \\
\text { Arisona }\end{array}$ & 1. Elon Davit Riadi \\
\hline 3. & NPM Berpengaruh Terhadap PER & $\begin{array}{l}\text { 1. Ryan El Zamzami, } \\
\text { Aulia dan Fuad } \\
\text { Rahman }\end{array}$ & $\begin{array}{l}\text { 1. Danta Sitepu dan } \\
\text { Johan Effendi }\end{array}$ \\
\hline
\end{tabular}

\section{PENUTUP}

Berdasarkan hasil pengolahan data sebelumnya dan analisa hasil maka bisa disimpulkan sebagai jawaban dari perumusan masalah dalam penelitian ini adalah sebagai berikut :

1. Variabel struktur modal (DER) tidak berpengaruh terhadap PER perusahaan manufaktur yang terdaftar di BEI periode 2013-2015.

2. Variabel ukuran perusahaan (Total Asset) tidak berpengaruh terhadap PER perusahaan manufaktur periode 2013-2015.

3. Variabel profitabilitas (NPM) berpengaruh terhadap PER perusahaan manufaktur periode 2013-2015.

4. Variabel struktur modal (DER), ukuran perusahaan (Total Asset) dan profitabilitas (NPM) berpengaruh terhadap PER perusahaan manufaktur periode 2013-2015.

Hasil penelitian menunjukan hanya variabel NPM yang berpengaruh terhadap PER, maka saran yang bisa diberikan oleh peneliti bagi penelitian selanjutnya 
1. Mencari variabel independen lain diluar variabel independen yang peneliti gunakan untuk memastikan sebenarnya variabel-variabel apa saja yang berpengaruh terhadap PER. Hal ini penting dilakukan mengingat PER merupakan indikator dari analisa perusahaan yang merupakan salah satu bagian dari analisa fundamental yang penting baik dalam melakukan analisa sekuritas.

2. Menggunakan indikator lain selain PER yang lebih tepat sebagai indikator analisa perusahaan

\section{Daftar Pustaka}

Arisona, Vivian Firsera. "Faktor-Faktor Yang Mempengaruhi Price Earning Ratio Pada Indeks LQ 45 Di Bursa Efek Indonesia," Jurnal Ilmu Manajemen, Volume 1 Nomor 1, Januari, 2013

Arthur J. Keown, David F. Scott, Jr., John D. Martin, J. William Petty, Manajemen Keuangan: Prinsip dan Penerapan Jilid 1 (Edisi Kesepuluh). Jakarta, PT. Indeks, 2010

Darmadji, Tjiptono dan Fakhrudin, Pasar Modal di Indonesia, Edisi Ketiga. Jakarta : Salemba Empat, 2011

Ghozali, Imam, Desain Penelitian Kuantitatif dan Kualitatif,Semarang, Yoga Pratama, 2013

Hayati, Nurul. "Faktor-Faktor Yang Mempengaruhi Price Earning Ratio (PER) Sebagai Salah Satu Kriteria Keputuan Investasi Saham Perusahaan Real Estate Dan Properti Di Bursa Efek Indonesia", Jurnal Manajemen dan Akuntansi, Volume 11, Nomor 1, April (2010)

Horne, James C. Van, John M. Wachowics, Jr. Prinsip-Prinsip Manajemen Keuangan, Jakarta, Salemba Empat, 2012.

Jogiyanto, Hartono, Teori Portofolio dan Analisis Investasi, BPFE Yogyakarta, Edisi Kedelapan, Yogyakarta, 2013

Kuncoro, Mudrajad, Metode Riset untuk Bisnis dan Ekonomi, Jakarta, Erlangga, 2014

L, Mulyani dan Pitaloka E." Pengaruh Return on Equity, Earning Per Share (EPS), dan Debt to Equity Ratio Terhadap Price Earning Ratio (PER) Pada PT. Indofood Sukses Makmur Tbk Periode 2012-2014', Widyakala, Volume 4 No.1 Maret (2017)

Priyatno, Duwi, SPSS 22: Pengolahan Data Terpraktis, Yogyakarta, Andi, 2014

Riadi, Elon Davit." Pengaruh Faktor Debt To Equity Ratio, Return on Equity dan Total Assets Terhadap Price Earning Ratio(PER) Pada Perusahaan Otomotif dan Komponen Yang Terdapat di Bursa Efek Indonesia (BEI)", e-Jurnal Manajemen, Vol 2, No 01 (2013)

Sitepu, Danta, dan Johan Effendi. “Analisa Faktor-Faktor yang Mempengaruhi Price Earning

Ratio Perusahaan Consumer Goods di Bursa Efek Indonesia", Jurnal Wira Ekonomi Mikroskil, Volume 4, Nomor 01, April (2014), 31-39

Tandelin, Eduardus, Potfolio dan Investasi. Teori dan Aplikasi,. Kanisius, Edisi Pertama, Yogyakarta, 2010

Utomo, Wawan, Rita Andini dan Kharis Raharjo. "Pengaruh Leverage (DER), Price Book Value (PBV), Ukuran Perusahaan (Size), Return On Equity (ROE), Deviden Payout Ratio (DPR) dan Likuiditas (CR) Terhadap Price Earning Ratio (PER) Pada Perusahaan Manufaktur Yang Listing di BEI Tahun 2009 - 2014”, Journal Of Accounting, Volume 2 No.2, Maret (2016)

https://idx.co.id/ 